\title{
Pengaruh Pemberian Pupuk Green Tonic dan Pupuk NPK Mutiara Terhadap Pertumbuhan Bibit Tanaman Kakao Forestero (Theobroma cacao L)
}

\section{Effect of Giving Green Tonic Fertilizer and Pearl NPK Fertilizer on Growth of Forestero Cocoa Plant Seeds (Theobroma cacao L)}

\author{
Ivan Wahyudi ${ }^{1}$, Mahdalena ${ }^{2}$ Hamidah $^{2}$ \\ 1 Alumni Program Studi Agroteknologi, Fakultas Pertanian, Universitas Widya Gama Mahakam \\ ${ }^{2}$ Tenaga Pendidik Program Studi Agroteknologi, Fakultas Pertanian, Universitas Widya Gama Mahakam \\ Jl. KH. Wahid Hasyim, Sempaja, Samarinda, Kalimantan Timur \\ e-mail:wahyudivan@gmail.com,mahdalena@uwgm.ac.id,hamidah@uwgm.ac.id
}

Diterima : 10 Mei 2018 Disetujui : 1 Juni 2018

\begin{abstract}
The Effect of Green Tonic Fertilizer and Pearl NPK Fertilizer on the Growth of Forestero Cocoa Plant Seeds (Theobroma cacao L) The aim of this study was to determine the effect of Green Tonic, NPK Mutiara and the extraction of Green Tonic and NPK Mutiara on cocoa seedling growth. This research was carried out at Gunung Panjang Samarinda Seberang East Borneo. with a time of \pm 3 months, starting from April to July 2016. The design of the study used factorial randomized block design (RCBD) $4 \times 4$ with a number of replications 3 times, with factorial analysis. The treatment consists of 2 factors. The first factor is the administration of POC Green Tonic consisting of 4 levels, namely: p0: Without treatment, p1: $2 \mathrm{ml} / 1$ Liter of Green Tonic Concentration, p2: $3 \mathrm{ml} / 1$ Liter of Water Tonic Concentration, p3: $4 \mathrm{ml}$ Green Tonic Concentration $/ 1$ Liter of Water, The second factor was the administration of NPK Mutiara consisting of 4 levels, namely: v0: Without treatment, v1: Giving NPK Mutiara Fertilizer 50 grams / polybag, v2: Giving NPK Mutiara Fertilizer 100 grams / polybag, v3: Giving NPK Fertilizer Pearl 150 grams / polybag. From the analysis of variance showed that the effect of giving green tonic liquid organic fertilizer $(P)$ was the best on the parameters of stem diameter of 30 DAP and 60 DAP of cocoa plants achieved by the treatment of $\mathrm{p3}$ (4 $\mathrm{ml} / 1$ Liter of Water Green Tonic Concentration), NPK Mutiara fertilizer $(V)$ the best in the parameters of plant height 30 DAP, 60 DAP and 90 DAP, stem diameter 30 DAP and 90 DAP, number of leaf 60 DAP, leaf area 30 DAP cocoa plants achieved by v3 (Giving NPK Pearl Fertilizer 150 gram / polybag) while for stem diameter $60 \mathrm{DAP}$, number of leaves $30 \mathrm{DAP}$ achieved by v1 (Giving NPK Mutiara Fertilizer $50 \mathrm{~g} / \mathrm{polybag}$ ), for the number of leaves 90 DAP, the area of Leaves 60 DAP and 90 DAP achieved by v2 (Giving NPK Pearl Fertilizer $100 \mathrm{~g} /$ polybag), The best interaction of POC green tonic and NPK pearl (PV) fertilizer on stem diameter parameters 30 DAP and 60 DAP, number of leaves of 90 DAP, leaf area of 60 DAP and 90 DAP was achieved by p3v2 (4 ml / 1 Liter Water + Green Tonic Concentration Pearl NPK fertilizer 100 grams / polybag. The difference for 30 HST leaf area is achieved by plv3 (2 Ton / 1 Liter Water + Green Tonic Concentration + 150 gram Pearl NPK Fertilizer / polybag).
\end{abstract}

Keywords: Green Tonic Fertilizer, NPK Fertilizer, Cocoa Plant Seed

\section{PENDAHULUAN}

Indonesia mempunyai potensi lahan yang bagus untuk mengembangkan sektor pertanian, termasuk tanaman perkebunan. Sebagai suatu kepulauan yang terletak didaerah tropis disekitar katulistiwa, indonesia memiliki beragam jenis tanah yang mampu menyuburkan tanaman, sinar matahari yg konsisten sepanjang tahun. Kondisi iklim yang memenuhi persyaratan tumbuh tanaman, dan khususnya di Kalimantan Timur. Produk perkebunan merupakan andalan ekspor hasil pertanian dan diperkirakan dapat meningkatkan pangsa pasar, dengan makin terbentuknya pasar di negara - negara mitra dagang. Menurut Susanto (2002), Kakao
(Theobroma cacao L) merupakan salah satu jenis tanaman perkebunan yang terus mendapat perhatian untuk dikembangkan. Upaya pengembangan tanaman kakao disamping masih diarahkan pada peningkatan populasi (Luas Lahan) juga telah banyak diarahkan pada peningkatan jumlah produksi dan juga hasil. Komoditi kakao merupakan salah satu komoditi ekspor non migas yang memiliki prospek cerah. Hasil olahan kakao seperti coklat pasta, coklat butter, coklat milk, dan lain-lain.

Era globalisasi, persaingan pasar berlangsung sangat kekat sehingga diperlukan strategi untuk memenuhi permintaan pasar, terutama terhadap pembinaan kepada petani atau produsen kakao untuk menghasilkan kualitas 
produksi yang diharapkan dengan berbagai produksi yang dapat dihasilkan oleh kakao maka prospek perkembangannya semakin mempunyai peran penting di masa yang akan datang.

Kakao merupakan sumber lapangan kerja dan pendapatan petani karena perkebunan kakao didominasi perkebunan rakyat yang dicapai $97 \%$ dari total perkebunan kakao. Kakao juga memiliki peranan penting dalam perekonomiam Indonesia karena indonesia sebagai negara produsen kakao terbesar ketiga dan peringkat ke 9 sebagai pengekspor kakao. Namun demikian, seperti diungkapkan oleh asosisasi penelitian perkebunan Indonesia perkakoan di Indonesia banyak menghadapi masalah. Dengan demikian, andai kata dari awal input sudah mengandung permasalahan, maka outputnya juga banyak mengandung masalah. Masalah yang berasal dari input antara lain benih kakao yang bukan berasal dari jenis unggul, serangan penggerek buah kakao (PBK), organisasi petani kakao yang belom berkembang, teknologi budidaya yang belum memadai.

\section{BAHAN DAN METODE}

Penelitian ini dilaksanakan selama 3 bulan, terhitung dari bulan April sampai dengan Juli 2016. Tempat penelitian dilaksanakan di kebun praktek percontohan Politeknik Pertanian Negeri Samarinda, Kecamatan Samarinda Seberang .Bahan yang digunakan dalam penelitian ini antara lain : bibit kakao, polybag $30 \times 30 \mathrm{~cm}$, paranet, pupuk Green Tonic, pupuk NPK Mutiara, air, tanah lapisan atas (Top Soil) Penelitian ini disusun dalam Rancangan Acak Kelompok (RAK) faktorial 4 x 4 dengan 3 ulangan. Faktor pertama yaitu perlakuan pupuk Green Tonic yang terdiri dari 4 taraf, yaitu : p0 $=$ tanpa perlakuan, $\mathrm{p} 1=$ konsentrasi green tonic $2 \mathrm{ml} / 1$ liter air, $\mathrm{p} 2=$ konsentrasi green tonic 3 $\mathrm{ml} / 1$ liter air, $\mathrm{p} 3=$ konsentrasi green tonic 4

\section{HASIL DAN PEMBAHASAN}

Hasil analisis sidik ragam menunjukkan bahwa pemberian pupuk cair Green Tonic (P) berpengaruh nyata terhadap parameter diameter batang 30 HST dan 60 HST. Diduga bahwa kandungan $\mathrm{N}$ pada Green Tonik lebih tinggi dibanding kandungan $\mathrm{P}$ dan $\mathrm{K}$ sehingga berpengaruh terhadap diameter batang tanaman kakao, hal ini sesuai dengan pendapat Nukuhaly (2012), dengan penyediaan $\mathrm{N}$ yang tinggi pada fase vegetatif akan mempercepat pembesaran batang. Menurut (Soetedjo, 2002), unsur $\mathrm{N}$
Hal ini terjadi karena industri perkebunan kakao di Indonesia sebagian besar merupakan industri rakyat. Masalah yang dihadapi dari output yaitu proses atau pengelolahan adalah kakao yang tidak dipermentasi, banyak mengandung kotoran, jasad reknik serta jamur. Masalah muncul karena proses pengeringan biji kakao yang tidak sesuai persyaratan sehingga kadar air masih cukup banyak. Hal ini mengakibtkan mutu produk kakao yang rendah yang pada akhirnya menyebabkan harga yang rendah untuk produk kakao di Indonesia. Dari hasil penelitian diharapkan dapat bermanfaat untuk bahan informasi bagi masyarakat atau pemerhati masalah bibit kakao untuk mempertimbangkan dosis pupuk dari terobosanterobosan baru di bidang pertanian bermunculan salah satunya adalah Green Tonic yang merupakan pupuk pelengkap cair. Pupuk diperlukan oleh tanaman karena pupuk dapat mempercepat proses pertumbuhan tanaman kakao.

$\mathrm{ml} / 1$ liter air dan faktor kedua yaitu dosis pupuk NPK Mutiara yang terdiri dari 4 taraf, yaitu : v0 = tanpa perlakuan, $\mathrm{v} 1=$ pemberian pupuk NPK mutiara 50 gram/polybag, $\mathrm{v} 2=$ pemberian pupuk NPK mutiara 100 gram/polybag, v3 = pemberian pupuk NPK mutiara 150 gram/polybag. Prosedur penelitian yaitu ; persiapan bibit, persiapan tempat penelitian, pengisian tanah ke polybag, penanaman bibit kakao, pemupukan, pemeliharaan (penyiraman, penyulaman dan penyiangan gulma. Parameter yang diambil yaitu ; tinggi tanaman, diameter batang, jumlah daun dan luas daun. Data dianalisis dengan menggunakan sidik ragam, apabila terdapat pengaruh pada sidik ragam maka dilakukan uji BNT pada taraf 5\% untuk membandingkan dua rata-rata perlakuan.

merupakan unsur utama vegetatif tanaman seperti pembentukan akar, batang dan daun. Sehingga jika unsur hara mencukupi kebutuhan tanaman maka pembentukan jaringan tanaman dapat berlangsung dengan baik dan cepat sehingga pembentukan akar, batang dan daun akan meningkat. Diperjelas oleh (Rismunandar dan Sukma, 2003), mengemukakan Nitrogen diperlukan dalam pembentukan sel-sel baru, Protein, Asam Amino, Enzim, Hijau daun dan Vitamin. Didukung oleh (Lingga, 2007) unsur hara tersebut bagi tanaman secara keseluruhan khususnya batang, cabang dan daun. Menurut (Lingga, 2000), bahwa pemberian pupuk 
organik cair Green Tonic tersebut mampu menyediakan nutrisi bagi tanaman kakao. Hal ini sejalan bahwa pupuk organik cair mengandung unsur hara makro dan mikro yang cukup lengkap, selain itu pupuk tersebut juga dapat diserap oleh tanaman. pupuk organik cair green tonic mampu mempercepat pertumbuhan generatif tanaman. Hasil sidik ragam menunjukkan bahwa pemberian pupuk NPK Mutiara (V) berpengaruh sangat nyata terhadap parameter luas daun 30 HST dan 90 HST, berpengaruh nyata pada parameter tinggi tanaman 30 HST, 60 HST dan 90 HST, diameter batang $30 \mathrm{HST}$, $60 \mathrm{HST}$ dan $90 \mathrm{HST}$, jumlah daun 30 HST, 60 HST dan 90 HST, luas daun 60 HST. Diduga kandungan unsur hara pada parameter tinggi tanaman, diameter batang, jumlah daun dan luas daun telah mencukupi kebutuhan tanaman dengan pemberian pupuk NPK Mutiara. Menurut Lukito (2010), pupuk $\mathrm{N}, \mathrm{P}, \mathrm{K}, \mathrm{Mg}, \mathrm{S}$ dan pupuk lainnya. Meningkatan pertumbuhan dan produktivitas tanaman selain itu bahwa pemberian pupuk merupakan faktor utama yang sangat penting dalam pemupukan, agar efektif pupuk harus diberikan di tempat dan disaat tanaman memerlukan. Rismunandar dan Sukma (2003), mengemukakan bahwa dengan membesarnya sel tanaman maka akan terbentuk vakuola sel yang besar yang mampu untuk menyerap air dalam jumlah yang banyak, sehingga makin bertambahnya jumlah dan ukuran sel tanaman, maka pembentukan protoplasma tanaman juga akan bertambah. Selanjutnya hal ini akan berpengaruh terhadap tinggi tanaman yang makin meningkat. Untuk memenuhi kebutuhan tanaman kita harus bisa menyediakan unsur hara dalam jumlah yang diperkirakan cukup dan seimbang (Parnata, 2004). Hasil analisis sidik ragam menunjukkan bahwa interaksi pemberian Pupuk Organik Cair Green Tonic dan pemberian pupuk NPK Mutiara $(\mathrm{PxV})$ berpengaruh sangat nyata terhadap parameter diameter batang $30 \mathrm{HST}$, luas daun 30 HST dan 90 HST. Berpengaruh nyata pada diameter batang $60 \mathrm{HST}$, jumlah daun 90 HST dan luas daun 60 HST.

Tabel 1. Pengaruh Perlakuan POC Green Tonic (P), dan NPK Mutiara (V) Terhadap Rata-rata Tinggi Tanaman dan Diameter Tanaman

\begin{tabular}{ccccccc}
\hline \multirow{2}{*}{ Perlakuan } & \multicolumn{3}{c}{ Tinggi Tanaman $(\mathrm{cm})$} & \multicolumn{3}{c}{ Diameter Tanaman $(\mathrm{mm})$} \\
\cline { 2 - 7 } & $30 \mathrm{HST}$ & $60 \mathrm{HST}$ & $90 \mathrm{HST}$ & $30 \mathrm{HST}$ & $60 \mathrm{HST}$ & $90 \mathrm{HST}$ \\
\hline p0 & 49,63 & 55,83 & 61,93 & $26.75 \mathrm{~b}$ & $29,69 \mathrm{c}$ & 34,40 \\
p1 & 50,63 & 56,35 & 63,50 & $24.95 \mathrm{c}$ & $32,99 \mathrm{~b}$ & 36,37 \\
p2 & 50,58 & 55,20 & 62,58 & $26.50 \mathrm{~b}$ & $33,79 \mathrm{~b}$ & 36,59 \\
p3 & 55,21 & 60,50 & 67,14 & $30.25 \mathrm{a}$ & $35,85 \mathrm{a}$ & 41,13 \\
v0 & $49,83 \mathrm{c}$ & $55,33 \mathrm{c}$ & $63,10 \mathrm{bc}$ & $23.97 \mathrm{~b}$ & $29,19 \mathrm{c}$ & $36,39 \mathrm{~b}$ \\
v1 & $50,90 \mathrm{~b}$ & $56,40 \mathrm{~b}$ & $62,55 \mathrm{c}$ & $28.13 \mathrm{a}$ & $35,16 \mathrm{a}$ & $37,38 \mathrm{ab}$ \\
v2 & $51,76 \mathrm{~b}$ & $57,25 \mathrm{~b}$ & $63,56 \mathrm{~b}$ & $28.28 \mathrm{a}$ & $33,98 \mathrm{~b}$ & $36,45 \mathrm{~b}$ \\
v3 & $53,55 \mathrm{a}$ & $58,90 \mathrm{a}$ & $65,94 \mathrm{a}$ & $28.08 \mathrm{a}$ & $33,99 \mathrm{~b}$ & $38,28 \mathrm{a}$ \\
p0v0 & 46,70 & 52,30 & 59.80 & $23.40 \mathrm{i}$ & $23,64 \mathrm{~g}$ & 33,00 \\
p0v1 & 48,30 & 54,50 & 59.10 & $28.70 \mathrm{bcd}$ & $35,47 \mathrm{~b}$ & 33,41 \\
p0v2 & 51,30 & 58,00 & 64.00 & $27.30 \mathrm{defg}$ & $26,05 \mathrm{f}$ & 33,58 \\
p0v3 & 52,20 & 58,50 & 64.80 & $27.60 \mathrm{cdef}$ & $33,60 \mathrm{de}$ & 37,62 \\
p1v0 & 51,70 & 56,50 & 63.90 & $19.57 \mathrm{j}$ & $26,10 \mathrm{f}$ & 34,70 \\
p1v1 & 49,80 & 55,50 & 62.00 & $26.40 \mathrm{efg}$ & $35,92 \mathrm{~b}$ & 38,67 \\
p1v2 & 46,90 & 52,90 & 59.70 & $25.80 \mathrm{gh}$ & $35,37 \mathrm{~b}$ & 33,87 \\
p1v3 & 54,10 & 60,50 & 68.40 & $28.02 \mathrm{bcdef}$ & $34,56 \mathrm{~cd}$ & 38,24 \\
p2v0 & 47,00 & 52,50 & 60.70 & $26.30 \mathrm{fg}$ & $33,02 \mathrm{e}$ & 38,08 \\
p2v1 & 50,50 & 56,30 & 63.70 & $28.10 \mathrm{bcde}$ & $34,07 \mathrm{de}$ & 37,45 \\
p2v2 & 51,30 & 55,00 & 62.40 & $24.50 \mathrm{hi}$ & $34,28 \mathrm{cde}$ & 33,33 \\
p2v3 & 53,50 & 57,00 & 63.50 & $27.10 \mathrm{defg}$ & $33,77 \mathrm{de}$ & 37,50 \\
p3v0 & 53,90 & 60,00 & 68.00 & $26.60 \mathrm{efg}$ & $34,01 \mathrm{de}$ & 39,78 \\
p3v1 & 55,00 & 59,30 & 65.38 & $29.30 \mathrm{bc}$ & $35,18 \mathrm{bc}$ & 40,00 \\
p3v2 & 57,55 & 63,10 & 68.12 & $35.50 \mathrm{a}$ & $40,21 \mathrm{a}$ & 45,00 \\
p3v3 & 54,40 & 59,60 & 67.05 & $29.60 \mathrm{~b}$ & $34,01 \mathrm{e}$ & 39,75 \\
\hline
\end{tabular}

Keterangan : Angka yang diikuti dengan huruf yang sama menunjukkan hasil tidak berbeda nyata berdasarkan uji BNT dengan taraf 5\% 
Tabel 2. Pengaruh Perlakuan POC Green Tonic (P), dan NPK Mutiara (V) Terhadap Rata-rata Jumlah Daun dan Luas Daun

\begin{tabular}{ccccccc}
\hline \multirow{2}{*}{ Perlakuan } & \multicolumn{3}{c}{ Jumlah Daun (helai) } & \multicolumn{3}{c}{ Luas Daun $\left(\mathrm{mm}^{2}\right)$} \\
\cline { 2 - 7 } & $30 \mathrm{HST}$ & $60 \mathrm{HST}$ & $90 \mathrm{HST}$ & $30 \mathrm{HST}$ & $60 \mathrm{HST}$ & $90 \mathrm{HST}$ \\
\hline p0 & 8.17 & 9.33 & 12.92 & 346.63 & 424.43 & 501.30 \\
p1 & 7.92 & 10.00 & 13.58 & 424.53 & 436.48 & 576.80 \\
p2 & 8.25 & 10.50 & 12.83 & 387.78 & 460.68 & 480.08 \\
p3 & 10.42 & 11.92 & 14.33 & 399.50 & 506.43 & 594.69 \\
v0 & $9,17 \mathrm{a}$ & $10.5 \mathrm{a}$ & $13.00 \mathrm{a}$ & $394.40 \mathrm{~b}$ & $435.30 \mathrm{c}$ & $501.95 \mathrm{c}$ \\
v1 & $8,67 \mathrm{ab}$ & $10.5 \mathrm{a}$ & $13.58 \mathrm{a}$ & $368.83 \mathrm{~d}$ & $451.00 \mathrm{~b}$ & $549.52 \mathrm{~b}$ \\
v2 & $8,50 \mathrm{~b}$ & $10.4 \mathrm{a}$ & $13.75 \mathrm{a}$ & $380.81 \mathrm{c}$ & $482.93 \mathrm{a}$ & $585.98 \mathrm{a}$ \\
v3 & $8,42 \mathrm{~b}$ & $10.33 \mathrm{a}$ & $13.33 \mathrm{a}$ & $414.40 \mathrm{a}$ & $458.78 \mathrm{~b}$ & $515.42 \mathrm{c}$ \\
p0v0 & 8,67 & 8.67 & $12.33 \mathrm{~g}$ & $347.90 \mathrm{ef}$ & $433.60 \mathrm{gh}$ & $558.50 \mathrm{ef}$ \\
p0v1 & 9,33 & 9.67 & $13.67 \mathrm{~cd}$ & $340.50 \mathrm{f}$ & $400.80 \mathrm{j}$ & $503.10 \mathrm{gh}$ \\
p0v2 & 6,00 & 9.00 & $12.33 \mathrm{~g}$ & $346.50 \mathrm{ef}$ & $439.10 \mathrm{fg}$ & $543.50 \mathrm{f}$ \\
p0v3 & 8,67 & 10.00 & $13.33 \mathrm{de}$ & $351.60 \mathrm{ef}$ & $424.20 \mathrm{hi}$ & $400.10 \mathrm{k}$ \\
p1v0 & 9,67 & 10.00 & $13.00 \mathrm{ef}$ & $396.40 \mathrm{~cd}$ & $415.40 \mathrm{i}$ & $463.40 \mathrm{ij}$ \\
p1v1 & 7,67 & 10.33 & $14.33 \mathrm{~b}$ & $358.80 \mathrm{ef}$ & $419.70 \mathrm{i}$ & $583.00 \mathrm{~cd}$ \\
p1v2 & 7,33 & 10.00 & $13.67 \mathrm{~cd}$ & $441.53 \mathrm{~b}$ & $462.60 \mathrm{~d}$ & $648.40 \mathrm{~b}$ \\
p1v3 & 7,00 & 9.67 & $13.33 \mathrm{~cd}$ & $501.40 \mathrm{a}$ & $448.20 \mathrm{ef}$ & $612.40 \mathrm{c}$ \\
p2v0 & 8,67 & 11.33 & $13.00 \mathrm{ef}$ & $429.90 \mathrm{~b}$ & $446.10 \mathrm{ef}$ & $484.10 \mathrm{hi}$ \\
p2v1 & 8,33 & 10.67 & $12.67 \mathrm{fg}$ & $410.91 \mathrm{c}$ & $463.70 \mathrm{~d}$ & $533.40 \mathrm{fg}$ \\
p2v2 & 9,00 & 10.33 & $13.00 \mathrm{ef}$ & $351.00 \mathrm{ef}$ & $455.30 \mathrm{de}$ & $466.90 \mathrm{ij}$ \\
p2v3 & 7,00 & 9.67 & $12.67 \mathrm{fg}$ & $359.30 \mathrm{e}$ & $477.60 \mathrm{c}$ & $435.90 \mathrm{j}$ \\
p3v0 & 9,67 & 12.00 & $13.67 \mathrm{~cd}$ & $403.40 \mathrm{c}$ & $446.10 \mathrm{ef}$ & $501.81 \mathrm{gh}$ \\
p3v1 & 9,33 & 11.33 & $13.67 \mathrm{~cd}$ & $365.10 \mathrm{e}$ & $519.80 \mathrm{~b}$ & $578.57 \mathrm{de}$ \\
p3v2 & 11,67 & 12.33 & $16.00 \mathrm{a}$ & $384.20 \mathrm{~d}$ & $574.70 \mathrm{a}$ & $685.11 \mathrm{a}$ \\
p3v3 & 11,00 & 12.00 & $14.00 \mathrm{bc}$ & $445.30 \mathrm{~b}$ & $485.10 \mathrm{c}$ & $613.27 \mathrm{c}$ \\
\hline Kenyyyyyy .
\end{tabular}

Keterangan : Angka yang diikuti dengan huruf yang sama menunjukkan hasil tidak berbeda nyata berdasarkan uji BNT dengan taraf 5\%

Hal ini diduga bahwa, kandungan unsur hara pada tanah dan pemberian kedua pupuk tersebut memenuhi kebutuhan unsur hara yang diperlukan oleh tanaman. Menurut (Soetedjo, 2002), unsur $\mathrm{N}$ merupakan unsur utama vegetative tanaman seperti pembentukan akar, batang dan daun. Jika unsur hara mencukupi kebutuhan tanaman maka pembentukan jaringan tanaman dapat berlangsung dengan baik dan cepat sehingga pembentukan akar, batang dan daun akan meningkat. Diperjelas oleh (Rismunandar dan Sukma, 2003), mengemukakan Nitrogen diperlukan dalam pembentukan sel-sel baru, Protein, Asam Amino, Enzim, Hijau daun dan Vitamin. Kekurangan Nitrogen mengakibatkan daun kuning, karena daunnya tidak banyak mengandung Klorofil. Jadi interaksi antara pupuk POC Green Tonic dan NPK mutiara dapat memenuhi unsur hara yang dibutuhkan oleh diameter, jumlah daun dan luas daun. Didukung oleh (Lingga, 2007) unsur hara tersebut bagi tanaman secara keseluruhan khususnya batang, cabang dan daun tanaman kakao.

\section{KESIMPULAN}

1. Pengaruh pemberian pupuk organik cair Green Tonic (P) yang terbaik pada parameter diameter batang 30 HST dan 60 HST tanaman kakao dicapai oleh perlakuan $\mathrm{p}_{3}$ (Konsentrasi Green Tonic $4 \mathrm{ml} / 1$ Liter Air).

2. Perlakuan pupuk NPK Mutiara (V) yang terbaik pada parameter tinggi tanaman 30 HST, 60 HST dan 90 HST, diameter batang 30 HST dan 90 HST, jumlah daun 60 HST, luas daun 30 HST tanaman kakao dicapai oleh $v_{3}$ (Pemberian Pupuk NPK Mutiara 150 gram/polybag) sedangkan untuk diameter batang 60 HST, jumlah daun 30 HST dicapai oleh $\mathrm{v}_{1}$ (Pemberian Pupuk NPK Mutiara 50 gram/polybag), untuk jumlah daun 90 HST, luas Daun 60 HST dan 90 
HST dicapai oleh $\mathrm{v}_{2}$ (Pemberian Pupuk NPK Mutiara 100 gram/polybag).

3. Interaksi pemberian POC Green Tonic dan pupuk NPK Mutiara (PV) yang terbaik pada parameter diameter batang 30 HST dan 60 HST, jumlah daun 90 HST, luas daun 60 HST dan 90 HST dicapai oleh $\mathrm{P}_{3} \mathrm{~V}_{2}$ (Konsentrasi Green Tonic $4 \mathrm{ml} / 1$ Liter Air +. Pupuk NPK Mutiara 100 gram/polybag). Seda ngkan untuk luas daun 30 HST dicapai oleh $\mathrm{p}_{1} \mathrm{v}_{3}$ (Konsentrasi Green Tonic $2 \mathrm{ml} / 1$ Liter Air + Pupuk NPK Mutiara 150 gram/polybag).

\section{DAFTAR PUSTAKA}

DISBUN $\quad$ KALTIM. 2014 Disbun kaltimprov.go.id/statis-36-komonditikakao.html.Samarinda.

Ensiklopedia Pupuk Indonesia, 2015. Pupuk NPK 16 -16- 16 Mutiara, Bogor.

Kristanto, A. 2010. Panduan Budidaya Kakao. Pustaka Baru Press. Yogyakarta.

Lingga, P 2007. Petunjuk Penggunaan Pupuk, Penebar Swadaya, Jakarta. $163 \mathrm{hlm}$.

Lingga, P dan Marsono, 2000. Petunjuk Penggunaan Pupuk, Penebar Swadaya, Jakarta. $163 \mathrm{hlm}$.

Lukito AM, Mulyono, Tetty $\mathrm{Y}$, Iswanto $\mathrm{H}$, Riawan N. 2010. Buku Pintar Budidaya Kakao. Agromedia Pustaka. Jakarta.
Lingga, P, 2007. Petunjuk Penggunaan Pupuk, Penebar Swadaya, Jakarta. $163 \mathrm{hlm}$.

Lukito, 2010. Pupuk Akar Jenis Dan Aplikasi. Penerbar Swadaya, Jakarta.

Nukuhaly, 2012. Pupuk Organik Cair dan Padat, Pembuatan dan Aplikasi. Swadaya. Jakarta.

Parnata, A.S. 2004. Mengenal Lebih Dekat Pupuk Organik Cair, Aplikasi dan Manfaatnya. Agromedia pustaka. Jakarta.

Petrokimia, 2005. Phonska; Pupuk Majemuk NPK. PT. Petrokimia Gersik.

Rismunandar, sukma, 2003. Pupuk Organik Cair Aplikasi Dan Manfaatnya. Agromedia Pustaka, Jakarta.

Siregar, THS, S Riyadi dan L. Nuraeni. 2012. Budidaya Pengolahan dan Pemasaran Coklat. Penebar Swadaya. Jakarta.

Soetedjo. M. M, 2002. Pupuk Dan Cara Pemupukan. Bhineka Cipta, Jakarta.

Susanto, 2002. Tanaman Kakao Budidaya dan Pengolahan Hasil, Kanisius. Yogyakarta.

Sutedjo. 2006. Pupuk Dan Cara Pemupukan. PT Bina Aksara, Jakarta.

Yan Utama Corporation. 2015. Pupuk Daun dan Aplikasi Untuk Tanaman. Jakarta. 